\title{
The Rise and Fall of the Early 'Abbāsid Political and Military Elite
}

\begin{abstract}
This paper explores the composition and role of the military and political elite of the early 'Abbāsid caliphate (750 - 809) whose support enabled the caliphs to maintain sovereignty over their far-flung domains. It considers the importance of different groups, including members of the 'Abbāsid family, military commanders from Khurāsān and members of powerful and wealthy families like the Muhallabīs and the Shaybāni tribal chiefs. The paper concludes with a discussion of the reasons for the disappearance and effective extinction of this elite in the years after the great civil war that followed Hārūn al-Rashīd's death in 809.
\end{abstract}

Keywords: Caliphs; armies; political power; Syria; Khurāsān

The governance of the early 'Abbāsid caliphate was a remarkable political and organizational achievement. For half a century, between the establishment of the dynasty in $132 \mathrm{H} / 750 \mathrm{CE}$ and the death of Hārūn al-Rashīd in 193 H/809 CE, the area from Tunisia in the west to Sind and Central Asia in the east was governed effectively and largely peacefully from Iraq. From $145 \mathrm{H} / 762 \mathrm{CE}$, the city of Baghdad served as the administrative capital, though the distances which separated it from the far-flung provinces were enormous: it is over 2,000 kilometres from Baghdad to Merv, the political centre of the great province of Khurāsān, and 1,500 kilometres from the capital to the Holy City of Mecca.

The barid postal system inherited from the Umayyads and Sasanians was surprisingly effective at communicating urgent messages over these huge distances. ${ }^{1}$ When the caliph al-Rashīd died in the year 809 at Țūs (near Mashhad in north-east Iran) a messenger brought the news to Baghdad in twelve days, traveling 1,900 kilometres at an average speed of 150 kilometres per day. Similar

\footnotetext{
I will not be dealing with the bureaucratic elite of the kuttāb or the religious elite of the fuqaha' and $q \bar{a} d \bar{s}$ s that would require a whole other study. For the general history of early 'Abbāsid caliphate, Kennedy 2016; El-Hibri 2010, 269-304; Bennison 2009. For earlier studies of the 'Abbāsid elite with full references to sources, Crone 1980, esp. 173-189, and Kennedy 1981/2016, $73-86$.
}

1 On the barid and the distances covered, see Silverstein 2007, 191-193.

Ә OpenAccess. ( 2020 Hugh Kennedy, published by De Gruyter. (cc) BY-NC-ND This work is licensed under the Creative Commons Attribution-NonCommercial-NoDerivatives 4.0 License. 
speeds are recorded for the reporting of other crucial events. Not until the invention of the electric telegraph in the late $19^{\text {th }}$ century was such swiftness bettered. Information was clearly very important.

Enforcement was much slower. Even without opposition or resistance, armies could travel no more than 20 kilometres a day, and usually managed less. That left plenty of time for a provincial rebellion to gather support and momentum before the forces of central government arrived on the scene. Exercising control and authority over such enormous distances was always going to be difficult, and demands for provincial autonomy were correspondingly hard to resist.

Despite these formidable obstacles the 'Abbāsids maintained their authority and the cohesion of their caliphate for more than half a century. No later Islamic dynasty established the same degree of authority over so wide and diverse an area. The achievement was not the result of absolutist authority, but of the development of a stable political and military elite, or rather a series of elites, which at the same time represented the caliphal government in the provinces and the provinces to the central government in Baghdad.

While this must have been true for all large pre-modern empires in the Middle East from the Achaemenids onwards, one factor that distinguishes the 'Abbāsid example is the wealth of information that survives in the sources about the government of the caliphate. In al-Tabarī's great Ta'rikh al-rusul wa-lmulūk (History of the Prophets and Kings), ${ }^{2}$ there are enough details to build up a detailed prosopography of the ruling elite, of their origins, connections, successes and failures. This is supplemented by universal chronicles such as alYa'qūbī's Ta'rīkh (History), ${ }^{3}$ and provincial accounts such as al-Kindī's Kitāb Wulāt Miṣr (Governors of Egypt) ${ }^{4}$ and al-Azdī's Ta'rīkh al-Mawșil (History of Mosul). ${ }^{5}$

Despite occasional contradictions, we can trace individual families through several generations in the evidence and get a clear idea of their influence. There is perhaps no other period in early Islamic history when so much attention was paid to the appointment of provincial governors and officials far away from the court and capital. It did not last. By the mid- $9^{\text {th }}$ century, the caliphate was dominated by the Turkish and eastern Iranian military of Samarra. Hardly any information survives regarding provincial appointments and we cannot reliably trace the names of governors, even of really important cities such as Basra. The care

\footnotetext{
2 Al-Ṭabarī 1879-1901.

3 Al-Ya'qūbī 1883.

4 Al-Kindī 1912.

5 Al-Azdī 1967.
} 
with which earlier annalists recorded this type of information clearly shows how important these people and the offices they held were then considered to be.

The key to these patterns of provincial power was the office of wāli, which is usually translated as governor. The richness of the sources means we can build up a virtually complete fasti of the governors of all the major provinces of the caliphate from the 'Abbāsid revolution to the reign of al-Ma'mūn, though (as is only to be expected) there are some confusions and ambiguities. The identities of the men who held these posts are an invaluable measure of the political complexities of the caliphate. The term 'âmil was also employed to designate this type of provincial official. The sources sometimes make a distinction between the office of wālì, in charge of leading prayers and the people in war, and the 'ämil, in charge of taxation, but the terms were often used interchangeably and the distinction between the two offices blurred. ${ }^{6}$

If the annals superficially make the caliph appear as a powerful absolute ruler, further down the chain of power the governors display effective executive power over military and civil affairs in the province. These areas are often simply characterised as harb and șalāt (war and prayer), but when sources like al-Kindì's history of Egypt allow us to peer below the surface, we find governors in a more complicated situation. ${ }^{7}$ The governors of Egypt were the middle men between the caliph and his government in Baghdad, which was always seeking to extract more tax revenue from this rich province, and the local Muslim elites, who were determined to retain as much of the revenue as possible in the local diw ān to pay their salaries and those of their followers. The governors' position was made more precarious in that they were usually outsiders with few Egyptian connections; they had to cooperate with or at least not alienate the wujūh, the local Arab Muslim elite. The wujūh were led by the șāhib al-shurța, the chief of police. Unlike the titular governor, the șăhib al-shurța was always chosen from a small circle of prominent local families and they often served for longer than their ephemeral superiors. At one level this seems a weak system of government, ultimately dependent on the consent of local notables. In reality the system was very resilient: the local Egyptian Muslim elite, who never held office outside their province and seldom left it, were stakeholders in the 'Abbāsid rule that assured their high status. One of the main reasons for the collapse of the caliphate in the $9^{\text {th }}$ century was the breaking of bonds between Baghdad and local elites by the influx of Turks and eastern Iranians to the top ranks of central government.

6 For an overview of the role of provincial governors, see $E I^{2}$, “Amïr” (A. A. Duri).

7 Kennedy 1981, 26-38; Kennedy 1998, 62-85; Mikhail 2014, esp. 136-159. 
The provincial elite was largely formed by the political genius of the second 'Abbāsid caliph Abū Ja'far al-Manșūr (136-158 H/754-775 CE). This cadre governed the vast 'Abbāsid Empire; its broad-based nature was vital in keeping the caliphate together politically and its disappearance after the great civil war that followed the death of al-Rashìd in $193 \mathrm{H} / 809$ CE was a major factor in the caliphate's breakup.

It is sometimes easy to forget how exceptional this pre-war period was and how impressive was the political success that kept this multi-ethnic, multi-cultural state together. In what follows, I will investigate some important constituents of the elite of this time to determine the sources of its power and the dynamics of its political operation.

The 'Abbāsid family formed an important element in this elite. ${ }^{8}$ The caliph's numerous uncles, the Banū 'Alī b. 'Abdallāh b. al-'Abbās, and his cousins were appointed to governorates in the western part of the caliphate, notably in Syria, Egypt and the prosperous and peaceful province of southern Iraq (most importantly in the city of Basra). They did not, however, serve in the Iranian provinces; al-Saffāh's brief appointment of one of his uncles as governor of Fārs was abruptly terminated by Abū Muslim. ${ }^{9}$ Nor did they serve in the Caucasus or North Africa, areas likely to see serious military activity and where Khurāsānī soldiers were stationed in large numbers. In some cases these 'Abbāsids formed sub-dynasties passing the title of governor from father to son, for example Ṣālih b. 'Alī (d. 152 H/769 CE) and his sons al-Faḍl (d. after 163 H/780 CE) and 'Abd al-Malik (d. 196 H/811-12 CE) in Syria, and Sulaymān b. 'Alī (d. 142 H/759-60 CE) and his son Muhammad (d. 173 H/789 CE) in Basra.

The granting of these prominent roles assured the loyalty of the wider 'Abbāsid family to the ruling branch of the dynasty, discouraging internecine rebellion or usurpation. Governors also provided a focus of dynastic loyalty for the people of the provinces. This is especially clear in the case of Syria. Many elements in this large and potentially turbulent province found themselves excluded from positions in the army with the end of Umayyad rule, but the patronage of Saalih and his sons assured the continuing loyalty of at least some of them to the 'Abbāsids. This was made very clear during the short reign of al-Amin, when 'Abd al-Malik b. Șālih was able to recruit large numbers of Syrians to support the caliph against the eastern Iranian armies of his brother al-Ma'mūn. ${ }^{10}$

8 This section expands on Kennedy 1981/2016, 73-95, where I first began to investigate the elite of the early 'Abbāsid caliphate.

9 Al-Ṭabarī 1879-1901, iii, 71-72.

10 Al-Ṭabarī 1879-1901, iii, 841-845. 
Members of the 'Abbāsid family were also wealthy property owners; for example, Șālih b. 'Alī, who took over most of the extensive property in northern Syria developed by Maslama b. 'Abd al-Malik and other Umayyad princes. This meant that even when they held no formal government position, the 'Abbāsids retained influence in their provinces. Although they visited the caliphal court in Baghdad, it seems that they resided in their own districts most of the time.

It is clear that al-Rashīd, or rather his Barmakid mentors, sought to undermine the power of these sub-dynasties. Upon Muhammad b. Sulaymān's death in Basra, his house and vast fortune were confiscated by the caliph. Neither his brother Ja'far or any children he may have had were allowed to inherit his position in the city. Similarly, 'Abd al-Malik b. Șālih spent the last six years of Hārūn's reign in prison because the caliph was apprehensive about the power he wielded in Syria. Members of the family were still property owners in comfortable circumstances but their place in the political elite was greatly diminished. After the death of 'Abd al-Malik b. Șālih in 195 H/811 CE no 'Abbāsid remained who could rally the Syrians to the support of the caliph as he and his father had been able to.

During the $3^{\text {rd }}$ century $\mathrm{H} / 9^{\text {th }}$ century $\mathrm{CE}$, the role of the 'Abbāsid family was greatly restricted. No members of the dynasty governed provinces or commanded armies except for the caliph, those of his children designated as heirs, and occasionally a brother-as in the case of al-Muwaffaq, brother of the caliph al-Mu'tamid (r. 256-279 H/870 - $892 \mathrm{CE}$ ) and leader of the campaign against the Zanj in southern Iraq. With these changes, the ruling dynasty became disconnected from the inhabitants of many of the provinces, for whom the 'Abbāsid family became an absent and increasingly irrelevant group.

Some other families who had been important in Umayyad times continued to be powerful under the new regime, either because they opposed the later Umayyads or because they offered support to the new dynasty allowing their previous allegiance to the old rulers to be conveniently overlooked. The most notable of these families were the Muhallabīs. ${ }^{11}$ Originally from the Azd tribes of 'Umān, the Muhallabīs rose to prominence in Umayyad service and played a major role in defeating the Khārijite rebellions that threatened the caliphate in Fārs and other areas of Iran. Al-Muhallab and his son Yazīd had been major figures in Umayyad politics, but in the later decades of Umayyad rule they had been marginalised. However, they still retained power and influence in the

11 For the general history of the family, see $E I^{2}$, "Muhallabids" (P. Crone), and Crone 1980, 133-35. For their role in the 'Abbāsid elite, Kennedy 1981/2016, 82-3, 190-2. 
city of Basra, and on the approach of the 'Abbāsid armies in 132 H/749 CE they brought the city over to the cause of the new dynasty. Over the coming decades, they were rewarded with important provincial governorates and military commands, notably in Egypt and North Africa and eventually in Sind as well. In North Africa they formed a minor dynasty referred to many centuries later by the local historian Ibn 'Idhārī (d. c. $712 \mathrm{H} / 1312 \mathrm{CE})^{12}$ as the dawlat al-muhāliba. If things had turned out differently, it might well have been the Muhallabis rather than the Aghlabids who were remembered as the first independent rulers of Muslim Ifrīqiya (Tunisia). In the event, their rule was terminated by the caliph al-Rashīd and their evanescent dawla disappeared. Nonetheless, the history of the family shows clearly that the 'Abbāsids had no qualms about making use of the talents and influence of these important supporters of the previous dynasty. The Muhallabiss brought with them influence in Basra itself and in the Basran trading networks that led from North Africa through Egypt (where there were $\mathrm{Mu}$ hallabī governors) to Basra and the Gulf and finally to Sind (where there were also Muhallabi governors). In return for governorships, the family brought the caliph influence in areas where 'Abbāsid armies seldom reached. It could be argued that the Muhallabīs mediated caliphal soft power in the southern fringes of the empire and among the merchant and commercial classes.

The most important source of military power for the caliphs was the group known collectively as the quwwād. The term qā'id (pl. quwwād) is one of a number of Arabic words for leadership used throughout Arabic historiography. In the early 'Abbāsid period the term had an almost technical meaning, describing the cadre of military officers who formed the backbone of the contemporary 'Abbāsid army. By tracing the careers of members of some of these families, we can establish a profile of the group and their trajectories. Among the well-known families were those of Mālik b. al-Haytham al-Khuzā'ī, Musayyib b. Zuhayr and al-Ḍabbī, 'Uthmān b. Nahīk al-'Akkī, 'Īsā b. Māhān and others. Here I have chosen to concentrate on two, the families of Khuzayma b. Khāzim alTamīmī and Qahțaba b. Shabīb al-Ṭầ'î. I shall also discuss the family of Ma'n b. Zā'ida al-Shaybānī, who though their origins were different had much in common with the other quwwād dynasties.

Almost all the quwwād came from Khurāsān. The first known members of this elite joined the armies of the 'Abbāsid revolution from 130 H/747 CE onwards. Many of them had served Abū Muslim, the leader of the revolution in Khurāsān, but changed their allegiance to the caliph al-Manșūr after Abū Muslim's execution. They all bore Arabic names and their nisbas show that they

12 Ibn 'Idhārī 1948. 
claimed to be descended from well-known Arab tribes. Whether this is actually true or they were Iranian mawāli who wanted to claim Arab origin is impossible to ascertain. They seem to have been Arabic speaking and the language of the army was probably Arabic, though it is likely that the Arabic-Persian hybrid language we now know as New Persian was developed in their ranks at this time. ${ }^{13}$ The non-Muslim populations of the Jazira were certainly aware of their eastern origins, and describe them as Persians. ${ }^{14}$

This elite had a number of distinctive features. Firstly it was geographically mobile. Members typically served in different provinces of the caliphate, returning to Baghdad between terms of office to be given new appointments. Alternatively they might enjoy a period of office in the capital itself by serving as members of the elite military units attached to the caliphal court, the shurta (police) and the haras (guard). When they were appointed to governorships or military commands, this was symbolised by the handing over of a liw $\bar{a}^{\prime}$ or banner of office. They were, in fact, an elite who owed their loyalty to Baghdad and the caliphate rather than to the provinces they governed, a truly pan-imperial cadre.

The leading figures among the quwwād retained contacts in the Khurāsāni places where their families originated. They may well have returned on visits and almost all the major families produced at least one provincial governor. At the same time they were also given properties called qațā'i (sing. qațīa) in Baghdad. ${ }^{15}$ Typically these included dwelling houses, a market, a square (rahba) and sometimes a mosque. They settled their troops in these urban quarters, where the men could benefit from the commercial opportunities afforded by the expanding new capital. It is likely that the quwwād families recruited soldiers from their native Khurāsān and from those of Khurāsānī descent who had settled in Baghdad. They may well have been responsible directly for the payment of salaries to their men, but we have no clear information regarding this.

The composition of the military following of the first family of quwwād studied here repays more detailed examination. The family of Khāzim b. Khuzayma al-Tamimīi $^{16}$ was closely connected with his town of origin: Marw al-Rūdh, a small city on the Murghāb river whose site now lies on the border between Uzbekistan and Afghanistan. When he was sent to 'Umān in 751/2 to fight the Khāri-

13 Bulliet 2009, 140 - 142, argues that New Persian emerged as a language used by cotton traders to do business. I would argue that it is at least as possible that it emerged among the Khurāsānī military contingents led by the 'Abbāsid period quwwād.

14 The Chronicle of Michael the Syrian (1899-1910) makes this very clear.

15 For the distribution of properties in Baghdad, see al-Ya'qūbī 1892, 140 - 55, now available in an English translation, al-Ya'qūbī 2018, I, 73-87.

16 Crone 1980, 180 -1; Kennedy 1981/2016, 81-2. 
jite rebels, his forces consisted of men from his ahl (family), his 'ashira (tribe), his mawālì (freedmen), the people of Marw al-Rūdh and some Tamimiss who joined him as he passed through Basra. All these men were in some way dependent on or related to him. Four years later he was fighting Khārijite rebels again, this time in the Jazira with 8,000 men of Marw al-Rūdh. In 758-759 he was ordered back to Khurāsān to fight the governor, who had rebelled against the caliph. On his approach the people of Marw al-Rūdh rose up against the rebels, captured their leader and handed him over to Khāzim, showing that despite some ten years absence in the west he still retained close links to his native town. When he died, his power and position passed to his son Khuzayma, who was able to raise 5,000 armed supporters in Baghdad on the night in 169 H/786 CE when the caliph al-Hādi died. The family owned a prestigious house in a central part of Baghdad, strategically placed at the east end of the city's main bridge of boats. In $198 \mathrm{H} / 813 \mathrm{CE}$, though Khāzim himself was old and blind, this house became a meeting place for supporters of al-Amin who wished to negotiate his peaceful surrender to Țāhir and the supporters of al-Ma'mūn. ${ }^{17}$

We are well informed about the family of Khāzim because of the high-profile campaigns he fought in, but he was likely typical of the $q \bar{a}$ 'id cadre. He raised the troops he commanded and he probably distributed their pay. He was in fact not a mere employee of the caliph, but (along with the rest of his family) a contractor who needed to be rewarded and respected for his services. Without the loyalty of such figures, the caliph would have been unable to maintain control over his vast empire.

Another typical family of quwwād were the descendants of Qahțaba b. Shabìb al-Ṭầ' $\overline{1},{ }^{18}$ but the trajectory of this elite family is rather different from that of Khāzim. Qaḥtaba came from the same Arab-Khurāsānī background as Khāzim. He had been the leader of the army Abu Muslim sent to the west to install the 'Abbāsids as caliphs, and would certainly have enjoyed a leading position under the new regime if he had not been killed crossing the Euphrates in the final stages of the campaign. He left two adult sons, al-Hasan and Humayd, who both enjoyed long but very different careers in the 'Abbāsid imperial elite. Al-Hasan took over his father's command and joined the siege of the last Umayyad governor Yazīd b. Hubayra in the old Umayyad garrison city of Wāsit. Here he came in contact with the caliph's brother Abū Ja far, later caliph himself under the title al-Manșūr. Together they forced the surrender of this last outpost of Umayyad resistance.

17 Al-Ṭabarī 1879-1901, III, 916.

18 For this family, see Crone 1980, 188-189; Kennedy 1981/2016, 79-80. 
The bond the two men struck up was the foundation of al-Hasan's subsequent career. He followed the future caliph when he became governor of the Jazira and provided him with crucial support in his final showdown with Abū Muslim in 755. He spent most of the rest of his long career on the Byzantine frontier and in Armenia. Here he worked closely with military leaders in the frontier districts (the thughür), leading expeditions deep in Byzantine territory and leading projects like the rebuilding of the frontier fortress of Malatya. Like all the leading quwwād he was given property in Baghdad (including a street, a rabad and houses) on which to settle his Khurāsānī followers. He died in 181 $\mathrm{H} / 797 \mathrm{CE}$ at the age of 84 , full of years and distinction.

By contrast, his brother Humayd was in some ways the black sheep of the family. He made a number of unwise career decisions that would normally have resulted in disgrace, if not execution. The fact that he survived shows how dependent successive caliphs were on the support and loyalty of these Khurāsānī families. While al-Ḥasan attached himself to the future caliph al-Manșūr, his younger brother took the side of the caliph's uncle 'Abdallāh b. 'Alī when he challenged al-Manșūr for the supreme title. However, 'Abdallāh also sought the support of the Syrian military elites who had supported the Umayyads. Deep-seated tensions between them and Ḥumayd's Khurāsānī followers meant he deserted before the final battle that saw al-Manșūr victorious.

Despite Humayd's support of al-Manșūr's rival, he was appointed governor of Egypt just five years later in $142 \mathrm{H} / 759 \mathrm{CE}$. He subsequently jeopardised his position yet again at the time of the great 'Alìd rebellion led by Muhammad the Pure Soul in $145 \mathrm{H} / 762 \mathrm{CE}$, when he fled the battlefield and almost caused a disastrous panic in the 'Abbāsid army. Once more he was rehabilitated, serving as governor of Armenia and finally in the most powerful position open to any of the Khurāsānī military elite: as governor of Khurāsān from 151 H/768 CE until his death in $159 \mathrm{H} / 776 \mathrm{CE}$. Like his brother, he had properties in Baghdad.

Both al-Hasan's and Humayd's sons carried on the family tradition. The third generation played an important role in supporting al-Amin against his brother al-Ma'mūn in the great 'Abbāsid civil war after the death of al-Rashìd. Like most of these families, the descendants of Qahțaba b. Shabīb lost everything during the long conflict. Their properties in Baghdad were destroyed and their connections with Khurāsān cut off. They were completely excluded from government office during the caliphates of al-Ma'mūn and al-Mu'tașim.

Not all of the families who constituted the military elite were of Khurāsāni origin and not all had supported the 'Abbāsid revolution. The family of Ma'n 
b. Zā'ida in fact broke most of the rules that might lead to advancement. ${ }^{19}$ They were the most prominent of the ashrāf (nobles) of the bedouin tribe of Shaybān, which dominated most of the northern Iraqi steppes. They had a substantial following among their fellow tribesmen and could bring experienced and hardy warriors to serve in the 'Abbāsid armies-but they also had fierce and determined enemies within their own tribe. As tribal leaders, they were opposed by Khārijite groups from Shaybān and by other tribes bitterly hostile to the ashrāf who served both Umayyad and 'Abbāsid caliphates.

Ma' $n$ b. Zā'ida had been a leading supporter of the last Umayyad caliph Marwān II; he went so far as to claim that it was he who killed Qaḥtaba b. Shabīb at time of the crossing of the Euphrates. Those two facts would have made relations with the new regime strained, to put it mildly. With his record, it would seem most improbable that his family would enjoy elite status under the 'Abbāsid caliphs. Yet that proved the case. Ma'n went perfunctorily into hiding after the fall of the Umayyads but he was clearly hovering, looking for an opportunity to ingratiate himself with al-Manșūr. His chance came with the rebellion of the Rāwandiyya, a group of radical Shīites, in Baghdad. It caught the caliph off his guard and Ma'n was present to save his life. After this al-Manșūr recognised that Ma'n, along with his Shaybānī tribesmen, was a valuable supporter. He was sent on distant and unglamorous postings to places like Yaman and Sīstān, and was killed in 152 H/772-773 CE in Bust (in the modern Helmand province of southern Afghanistan) when a group of Khārijites dug through the flat roof of his house and surprised him.

He seems to have left no sons. His position within the tribe and his feud with the Khārijites was inherited by his nephew Yazīd b. Mazyad, whom Khārijites pursued to Baghdad and attempted to murder on the city's bridge of boats. Yazīd b. Mazyad became a leading military commander in the reign of alMahdī but found himself on the wrong side of a major political conflict when the caliph was succeeded by his son Mūsā al-Hādī. Mūsā enjoyed strong support among military leaders and Yazīd played an important part in this. He is said to have been among those who urged the new caliph to remove his brother Hārūn from the succession and to execute his mentor and leading supporter Yahyā the Barmakid. In the event, the sudden death of Mūsā al-Hādī and Hārūn's accession meant that Yazīd, like other quwwād, was in deep disgrace and perhaps lucky to escape with his life.

Apart from a short spell as governor of Armenia, Yazìd remained in the political wilderness for almost a decade until the caliph was once more in need of

19 For this family, see Crone 1980, 169-170. 
his military abilities and tribal following. The Jazira was disturbed by a widespread Khārijite rebellion led by the charismatic and romantic figure of alWalīd b. Tarīf al-Shārī, who was said to have been from the same Shaybānī tribe as Yazidd. The forces sent by the Barmakid administration were unable to deal with these fast-moving opponents until, despite the advice of Yahyā b. Khālid, the caliph called on the services of Yazìd. He led his tribal following ('ashïra) against the enemy, defeated the rebels and killed their leader al-Walid, whose grief-stricken sister composed one of the greatest laments in classical Arabic literature on his death. Yazīd was now firmly back in favour with the caliph. His career prospered and he served Hārūn in Khurāsān, on the Byzantine frontier and in Armenia, where he died in $185 \mathrm{H} / 801 \mathrm{CE}$.

His son Asad inherited his tribal following and it would seem his prestige. During the great civil war, he was a vigorous supporter of al-Amin and was known as färis al-'arab, the 'knight of the Arabs'. Like his father and uncle, he was looked up to as an exemplar of the ancient bedouin virtues of courage and generosity. Unfortunately, the defeat of al-Amin meant that Asad lost power and influence. He had no place in the new 'Abbāsid caliphate as it was reconstructed by al-Ma'mūn and al-Mu'tașim; Arab tribal followings were not allowed to participate in the new military organization of the time, dominated as it was by eastern Iranians and Turks. However, unlike many of the other quwwād families under discussion here, the Shaybānī ashrāf reinvented themselves, survived and prospered.

In $171 \mathrm{H} / 787$ CE Hārūn had appointed Yazīd b. Mazyad as governor of Azerbayjan, a province requiring a firm military hand to keep the locals peaceful whilst defending them from the Khazars to the north. ${ }^{20}$ When he died in the provincial capital of Bardha'a, his son Asad was appointed to succeed him. It seems as if the family connection with the province continued. In 245 H/859-860 CE the caliph al-Mutawakkil appointed Yazīd's grandson Muhammad b. Khālid as governor of Bāb al-Abwāb (Derbent) and its surrounding districts. "He rebuilt the city of Ganja and was granted it and the estates ( tary possessions (irthan)".

With the assassination of al-Mutawakkil in the next year, caliphal control over the Caucasus effectively collapsed and left the family in control. In the years to come the descendants of Ma'n b. Zā'ida changed their collective identity and with it their familial claim to leadership. Instead of being ashrāf of Shaybān, they took the ancient Iranian title of Shirvān Shāh and claimed descent from the

20 For the complicated events taking place in Azerbayjan in the $3^{\text {rd }}$ century $\mathrm{H} / 9^{\text {th }}$ century CE, see Madelung 1975, 243-249. 
semi-mythical Sāsānian hero Bahram Gur. ${ }^{21}$ Beginning with Manuchehr, who succeeded in $418 \mathrm{H} / 1028 \mathrm{CE}$, the members of the family bore Persian rather than Arab names. The dynasty survived in the eastern Caucasus in one form or another until the mid-13 $3^{\text {th }}$ century, coincidentally disappearing at almost the same time as the 'Abbāsids finally lost Baghdad.

The Shaybānī elite survived when other families of quwwād lost their status and identity for a number of reasons. The most important was their enjoyment of tribal support that was not necessarily dependent on salaries from the dīwān in Baghdad or revenues from Khurāsān. Though the tribe was clearly divided between supporters of the ashrāf and supporters of the Khārijites, there were tribesmen who had followed their leaders and settled in Azerbayjan where the family established their power base in later generations, having an almost hereditary position in the eastern Caucasus before the death of Hārūn and the great civil war. Although they fought on the losing side that time, they had a power base beyond the reach of al-Ma'mūn and his victorious general Tāhir. They did not even suffer from the loss of their property in Baghdad after the civil war, because seemingly they never had any. As we have seen, the family survived, but only by adapting themselves to new circumstances in new areas and adopting an entirely new political personality: as Iranian shahs, not Arab ashrāf.

The last family I want to consider in detail is that of al-Ash'ath b. Qays alKindī. Their history illustrates another pattern of continuity and survival among the elite of the Umayyad and early 'Abbāsid caliphates. Descended from the kings of the great south Arabian tribe of Kinda, the family of al-Ash'ath came from the highest echelons of the pre-Islamic Arab nobility. Al-Ash'ath himself had pledged allegiance to the Prophet but joined the ridda (apostasy) after his death. Despite this, because of their status as tribal leaders the family still remained influential among the Kindīs who settled in Iraq during the Umayyad period. Al-Ash'ath's grandson, 'Abd al-Rahmmān, led the last great, unsuccessful rebellion of the ashrāf of the Iraqi tribes against the Umayyads in $82 \mathrm{H} / 701 \mathrm{CE}$. Under the early 'Abbāsids, the Kindī leaders enjoyed a modest revival of their power, with several of their members appointed as governors of Kufa.

Unlike the Shaybānīs, who could clearly mobilise a nomad force from their tribesmen, the influence of the Kindīs seems to have been urban and based in the city of Kufa. Though they never reached the top ranks of the 'Abbāsid elite, they were important in securing the loyalty of the people of Kufa to the 'Abbāsid cause, especially when faced with the 'Alìd rebellion of Muhammad the Pure Soul in Medina in $145 \mathrm{H} / 762$ CE. The fact that the city, so turbulent in

21 See Vacca 2017, 144-145. 
Umayyad times, was peaceful throughout the first 'Abbāsid half-century must have been in part due to their influence.

This was the family that produced the famous intellectual Ya'qūb b. al-Sibāh al-Kindī, known as the 'philosopher of the Arabs'. Like many of the leading figures in Kufa, he had moved to Baghdad as the city lost economic and political status in favour of the capital. Ya'qūb seems to have built up his famous library from the wealth he inherited from his illustrious family, but appears to have had no personal military or political ambitions himself. With his death, we lose touch with the family, but their story is an interesting one of elite survival and progressive adaptation to the Rāshidūn, to the Umayyads and to the 'Abbāsids. They moved from tribal leaders, to defeated rebels, to functionaries of the 'Abbāsid state, and finally to the intellectual eminence that ensured the Kindi name was the only one of the early 'Abbāsid elite families to remain well-known in later centuries, as its reputation spread to the cathedral schools and universities of western Europe.

The dominance of this early 'Abbāsid elite was ended by the great civil war that followed the death of the caliph al-Rashīd in 193 H/809 CE. His son al-Amin enjoyed the support of most of the early 'Abbāsid elite. Led by 'Alī b. 'İsā b. Māhān, the quwwād of the Khurāsāniyya were defeated near Rayy in northern Iran by the much smaller army of the supporters of al-Ma'mūn. Although some figures of the elite remained at al-Ma'mūn's court, the army commanders (notably Țāhir b. al-Ḥusayn) came from eastern Iranian families with no previous connection with the 'Abbāsid court. They had been thoroughly alienated from it by the harsh taxation policies of 'Alī b. 'İsā.

This defeat, and the subsequent siege and ruin of Baghdad, destroyed the power base of much of the elite. The quwwād no longer enjoyed the financial support of the government to recruit and pay their followers, and they were cut off and excluded from their ancestral homes in Khurāsān. None of the $q u w w \bar{a} d$ families who had dominated the military structures of the early 'Abbāsid caliphate played any important role in the caliphate re-established by alMa'mūn and al-Mu'tașim. The only member of the group known to us is Nașr al-Khuzā'i -and not as a supporter of the caliphate, but as the man who led the rebellion in Baghdad protesting the enforcement of the doctrine of the createdness of the Qur'ān.

It was not only the quwwād whose power was destroyed by the coming of the new order. The members of the 'Abbāsid family who had played such important roles in the early 'Abbāsid elite, representing the family (so to speak) in the great cities of Basra and Kufa, in the sawād of Iraq, Syria and sometimes Egypt, disappear at this time from the political stage. It is a sign of the changes in the early $3^{\text {rd }}$ century hijri that the sources no longer tell us the names of the governors of 
these great cities and provinces, except when they are involved in some disturbance or battle like the defence of Basra against the Qarāmița. When we are told their names, they are always members of the Turkish and eastern Iranian military, not members of the ruling family. We are informed incidentally that the descendants of the great 'Abd al-Malik b. Șāliḥ, effective ruler of much of northern Syria, still lived in the neighbourhood of Manbij where he had constructed a celebrated palace, but there is no indication they played any part in the political life of the province. The provincial elites could no longer look to the patronage and protection of 'their' members of the ruling family, and this connection with the dynasty was lost.

The elite of the early 'Abbāsid caliphate is remarkable in Islamic history because of its variety, its broad base and its many contacts. We cannot understand the history of this great dynasty unless we look beyond the narrative of the actions of the caliphs to those who supported and influenced them.

\section{Bibliography}

\section{Primary Sources}

al-Azdī, Abū Zakariyyā' Yazīd b. Muḥammad (1967), Ta'rīkh al-Mawşil, ed. by 'A. Ḥabība, Cairo.

Ibn 'Idhārī, Aḥmad b. Muḥammad (1948), Kitāb al-Bayān al-mughrib, ed. by G. S. Colin and E. Levi-Provencal, Leiden: E. J. Brill.

al-Kindī, Muhammad b. Yūsuf (1912), The Governors and Judges of Egypt, ed. by Rhuvon Guest, Leiden etc.: E. J. Brill.

Michael the Syrian (1899-1910), Chronicle, reproduced [vol. IV] and trans. [vols.I-III] by Jean-Baptiste Chabot, 4 vols., Paris: Leroux.

al-Ṭabarī, Muḥammad b. Jarīr (1879-1901), Ta'rīkh al-rusul wa-l-mulūk, ed. by M. J. de Goeje, 16 vols., Leiden: E. J. Brill.

al-Ya'qūbī (1883), Ta'rīkh al-Ya'qūbī, 2 vols., ed. by M. T. Houtsma, Leiden: E. J. Brill. al-Ya'qūbī (1892), Kitāb al-Buldān, ed. by M. J. de Goeje, Leiden: E. J. Brill.

al-Ya'qūbī (2018), The Works of Ibn Wādịh al-Ya'qūbī, ed. and trans. by Matthew S. Gordon et al., 3 vols., Leiden: E. J. Brill.

\section{Studies}

Bennison, Amira K. (2009), The Great Caliphs: The Golden Age of the Abbasid Empire, London/New York: I.B. Tauris.

Bulliet, Richard (2009), Cotton, Climate, and Camels in Early Islamic Iran: A Moment in World History, New York: Columbia University Press. 
Crone, Patricia (1980), Slaves on Horses: The Evolution of the Islamic Polity, Cambridge: Cambridge University Press.

$\mathrm{El}^{2}=\mathrm{P}$. Bearman et al., eds. (1960-2007), The Encyclopaedia of Islam, Second Edition, Leiden: Brill.

el-Hibri, Tayeb (2010), “The Empire in Iraq, 763-861”, in: Chase Robinson, ed., New Cambridge History of Islam, I, Cambridge: Cambridge University Press, 269-304.

Kennedy, Hugh (1981), "Central Government and Provincial Elites in the Early 'Abbāsid Caliphate", Bulletin of the School of Oriental and African Studies 44.1: 26-38.

Kennedy, Hugh (1981/2016), The Early Abbasid Caliphate: A Political History, London: Croom Helm/Routledge.

Kennedy, Hugh (1998), “Egypt as a Province in the Islamic Caliphate, 641-868”, in: Carl F. Petry, ed., The Cambridge History of Egypt, I, Cambridge: Cambridge University Press, 62-85.

Kennedy, Hugh (2016), The Prophet and the Age of the Caliphates, $3^{\text {rd }}$ ed., London/New York: Routledge.

Madelung, Wilferd (1975), “The Minor Dynasties of Northern Iran”, in: Richard N. Frye, ed., The Cambridge History of Iran, VI, Cambridge: Cambridge University Press, 198 - 249.

Mikhail, Maged S. A. (2014), From Byzantine to Islamic Egypt: Religion, Identity and Politics After the Arab Conquest, London: I. B.Tauris.

Silverstein, Adam J. (2007), Postal Systems in the Pre-Modern Islamic World, Cambridge: Cambridge University Press.

Vacca, Alison (2017), Non-Muslim Provinces under Early Islam, Cambridge: Cambridge University Press. 
